InFestasi

Vol. 17 No. 2 Desember 2021

Hal. 93-104

\title{
Green Intellectual Capital dan Sustainable Performance Green Intellectual Capital and Sustainable Performance
}

\author{
Alifira Nabila Zalfa ${ }^{1}$, Nova Novita ${ }^{2}$
}

STIE Indonesia Banking School

A R T I C L E INFO

Article History:

Received

Revised

Publish

\section{Keywords:}

Green Intellectual Capital, Green Human Capital, Green Structural Capital, Green Relational Capital, Sustainable Performance, Sustainable Business

DOI:

\begin{abstract}
A B S T R A C T
This research proposes to investigate the effect of Green Intellectual Capital on Sustainable Performance. The analysis further tests the influence of Green Human Capital, Green Structural Capital, and Green Relational Capital on Sustainable Performance. The sample used in this research is Fashion SMEs inJabodetabek region. By using the convenience sampling method obtained 131 respondents through Instagram, market place and Facebook. The results prove that Green Human Capital has a negative effect on Sustainable Performance and a positive influence of Green Relational Capital on Sustainable Performance. This research fails to demonstrate the impact of Green Structural Capital on Sustainable Performance. This finding shows that SMEs need support in developing their human resources, especially in creating a green business to save their expenses. The research also indicates that integrated an environmentally friendly business ecosystem into the value chain can improve the performance of SMEs. Support in training, preparation of quality certification and seminars can encourage SMEs to establish operational structures that promote sustainable business practices.
\end{abstract}

\section{A B S T R A K}

Penelitian ini bertujuan untuk menguji pengaruh Green Intellectual Capital terhadap Sustainable Performance. Lebih lanjut lagi menguji pengaruh Green Human Capital, Green Structural Capital, dan Green Relational Capital terhadap Sustainable Performance. Penelitian ini ditujukan kepada pelaku bisnis UMKM Fashion yang terdapat di Jabodetabek. Sampel yang diperoleh dalam penelitian ini sebanyak 131 responden diperoleh secara convenience dengan memanfaatkan Instagram, market place dan Facebook. Hasil penelitian membuktikan adanya pengaruh negatif Green Human Capital terhadap Sustainable Performance dan pengaruh positif Green Relational Capital terhadap Sustainable Performance. Riset ini gagal membuktikan adanya pengaruh antara Green Structural Capital terhadap Sustainable Performance. Temuan ini menunjukkan bahwa pelaku UMKM membutuhkan dukungan dalam mengembangkan sumberdaya manusia yang mampu mewujudkan sebuah bisnis yang berwawasan lingkungan, sehingga pelaku UMKM dapat menghemat pengeluarannya. Hasil riset juga menunjukkan bahwa sebuah ekosistem bisnis ramah lingkungan yang terintegrasi dalam value chain mampu meningkatkan kinerja UMKM. Dukungan dalam bentuk pelatihan, persiapan sertifikasi mutu maupun seminar dapat mendorong UMKM untuk membentuk struktur operasional yang yang mendorong kearah praktik bisnis berkelanjutan.

\section{PENDAHULUAN}

*Corresponding author: nova.novita@ibs.ac.id 
Kinerja usaha yang berkelanjutan merupakan salah satu indikator keberhasilan perusahaan dalam menghadapi persaingan. Kinerja keberlanjutan umumnya berkaitan dengan besar kecilnya usaha. Sekalipun teruji meski saat krisis, daya saing Usaha Mikro, Kecil dan Menengah (UMKM) masih menjadi isu yang menarik untuk diperbincangkan. Rendahnya daya saing UMKM disinyalir diakibatkan oleh rendahnya mutu, kurang berkembangnya inovasi dan kurang mengupayakan pelestarian sumber daya alam (Yanti, dkk, 2018). Argumen ini diperkuat oleh perbandingan data UMKM Indonesia dengan Malaysia, Thailand, Filipina dan Vietnam, dimana Global Value Chain (GVC) UMKM Indonesia masih rendah dibanding negara tetangga (Koperasi \& UMKM, 2019). Global value chain (GVC) merupakan suatu proses untuk menghasilkan suatu produk barang jadi yang melibatkan beberapa negara yang terdiri mulai dari proses produksi hingga proses pemasarannya. GVC juga dapat berperan dalam mendorong peningkatan lapangan kerja dan pertumbuhan ekonomi serta peningkatan standar hidup suatu negara.

Riset pemetaan dan strategi peningkatan daya saing Departemen Pengembangan UMKM Bank Indonesia tahun 2016 mencatat bahwa kontribusi UMKM terhadap PDB negara-negara ASEAN hanya 42\%, meskipun jumlah usaha UMKM mencapai 96\% dari total keseluruhan usaha (bi.go.id). Keikutsertaan Indonesia dalam GVC merupakan pengembangan kegiatan ekonomi yang berkualitas, dengan demikian Indonesia mampu meningkatkan pemanfaatan GVC dan jaringan produksi global untuk menghasilkan barang dan jasa berorientasi ekspor.

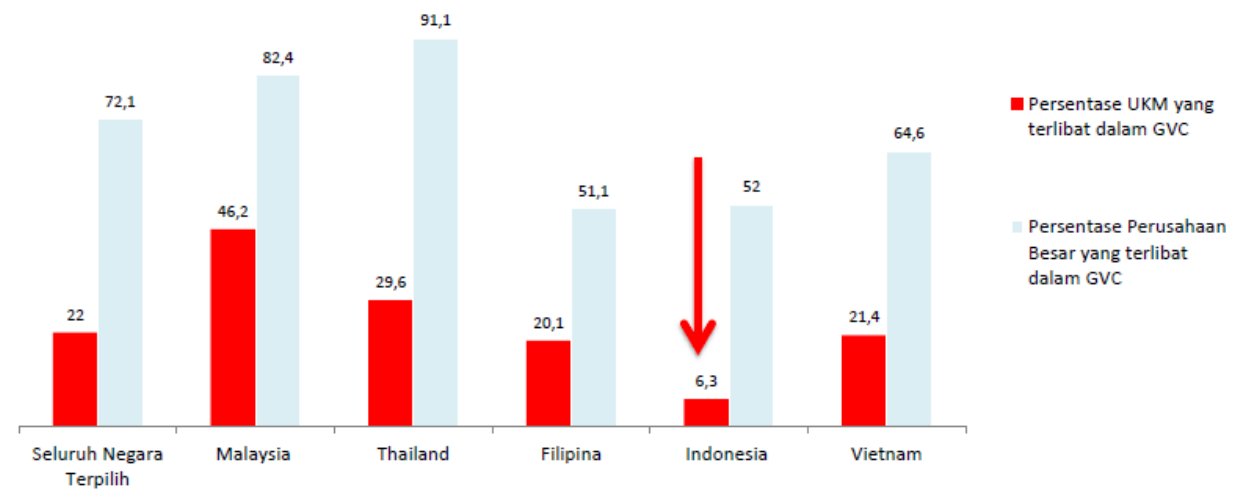

Gambar 1.1. Peran UKM dalam Global Value Chain di wilayah Asia Tenggara

Sumber: (Koperasi \& UMKM, 2019)

Grafik di atas menunjukkan bahwa, keterlibatan sektor UMKM Indonesia dalam GVC masih terbilang sangat rendah, terutama dalam ekspor produk manufaktur (Koperasi \& UMKM, 2019). Keterlibatan sektor UMKM indonesia dalam GVC sangat rendah, hanya 6.3\% jika dibandingkan lima negara lainnya dari total UMKM yang ada di Indonesia yang mampu terlibat dalam GVC di wilayah Asia Tenggara. Hal ini tentunya menunjukkan rendahnya daya saing UMKM Indonesia di pasar global dan hal ini dapat menjadi sinyal ancaman keberlanjutan usaha UMKM. Bisnis UMKM yang berkelanjutan dapat dimulai dengan mengadopsi konsep sustainable business.

Agenda Sustainable Development Goals (SDGs) menjadi perhatian setiap negara. SDGs merupakan kelanjutan Millennium Development Goals (MDGs) yang disepakati oleh negara anggota PBB pada tahun 2000 dan berakhir pada akhir tahun 2015. SDGs merupakan inisiatif global yang bertujuan untuk menciptakan kehidupan manusia menjadi lebih baik dalam aspek sosial dan ekonomi serta dapat bersinergi dengan lingkungan (Panuluh \& Fitri, 2016). SDGs memiliki 5 prinsip yang diharapkan mampu meyeimbangkan perekonomian antara lain people (manusia), planet (bumi), prosperity (kemakmuran), peace (perdamaian), dan partnership (kerjasama). Penerapan Sustainable Development Goals (SDGs) sangat membantu perusahaan di Indonesia bertumbuh, tidak terkecuali UMKM. Implementasi prinsip SDGs di dunia bisnis akan mengurangi potensi konflik di wilayah operasi perusahaan, sembari membangun hubungan baik dengan masyarakat sekitar dan pemerintah (Sindonews.com, 2019), hal tersebut sesuai dengan salah satu tujuan SDGs dalam mengembangkan program pengembangan industri kecil dan menengah (SDG2030indonesia.org, 2017). Penerapan SDGs di sektor UMKM diharapkan dapat mendorong terciptanya inovasi baru dan solusi bisnis ramah lingkungan demi terwujudnya usaha yang berkelanjutan. Selain itu secara tidak langsung memberikan dukungan terhadap pelaksanaan SDGs di Indonesia. Meningkatnya kesadaran tentang green product menuntut perusahaan menerapkan green business, yang tentunya membutuhkan human capital yang memiliki wawasan dan pemahaman mengenai green business tidak terkecuali UMKM. 
Green Intellectual Capital merupakan salah satu aspek yang dapat mendukung upaya menjaga lingkungan sekitar demi tercapainya sustainable performance. Green intellectual capital merupakan aset tidak berwujud berupa sumber daya informasi, inovasi serta pengetahuan yang berfungsi untuk meningkatkan kemampuan bersaing dengan tetap melindungi lingkungan yang mampu meningkatkan sustainable performance (Yusliza et al., 2019). Green intellectual capital dijelaskan melalui tiga indikator antara lain green human capital, green structural capital, dan green relational capital. Memiliki modal sumberdaya manusia yang memahami green business, struktur dan komitmen organisasi yang menunjang untuk penerapan green business serta adanya hubungan yang baik dengan stakeholder akan akan mendorong terciptanya produkproduk ataupun jasa yang ramah lingkungan, yang saat ini diminati konsumen. Hal ini tentu akan meningkatkan penjualan, sehingga dari sisi bisnis tetap menguntungkan, namun dari sisi lingkungan dan sosial tidak dirugikan. Pandangan ini dibuktikan dalam sejumlah penelitian seperti penelitian Mohd, et al (2019) yang menemukan bahwa Green Intellectual Capital berpengaruh positif terhadap Business Sustainability. Green intellectual capital juga terbukti mempengaruhi sustainable performance pada penelitian Yusliza et al., (2019), Hasil serupa juga ditemukan dalam penelitian Ullah et al., (2021) dan Wang and Juo (2021). Namun demikian hasil berbeda ditemukan pada penelitian Mohd et al., (2019), bahwa hanya green structural capital dan green relational capital memiliki pengaruh positif terhadap business sustainability, sedangkan green human capital tidak memiliki pengaruh terhadap business sustainability. Hasil beragam juga di temukan dalam penelitian Yusoff et al. (2019), bahwa green structural capital dan green relational capital berpengaruh positif terhadap kinerja, namun green human capital tidak.

Penelitian ini merupakan penelitian replikasi dari penelitian Mohd et al., (2019) yang menguji hubungan antara green intellectual capital berpengaruh positif terhadap business sustainability. Berbeda dari penelitian Mohd et al., (2019) yang mengumpulkan data dari UMKM manufaktur yang hanya berada di Malaysia, peneliti tertarik untuk melakukan penelitian pengaruh Green Intellectual Capital terhadap Sustainable Performance pada UMKM Fashion Bisnis di Jakarta. Alasan penulis meneliti UMKM karena melihat kontribusi UMKM terhadap Produk Domestik Bruto dan melihat keterserapan tenaga kerja pada UMKM yang sangat besar.

Produk Domestik Bruto (PDB) adalah jumlah nilai tambah yang dihasilkan oleh seluruh unit usaha dalam suatu negara tertentu, atau merupakan jumlah nilai barang dan jasa akhir yang dihasilkan oleh seluruh unit ekonomi (Bank Indonesia, 2015). Berdasarkan data dari (Depkop.go.id, 2018) yang telah diolah oleh Badan Pusat Statistik, terdapat peningkatan kontribusi UMKM terhadap PDB atas dasar harga berlaku dari tahun 2017-2018 dimana dari angka 60.90\% meningkat menjadi 61,07\%. Tidak hanya berkontribusi dalam PDB, namun juga UMKM membuka lapangan kerja yang tentunya banyak menyerap tenaga kerja (Bank Indonesia, 2015). Hal tersebut dibuktikan oleh (Depkop.go.id, 2018) dimana terjadi peningkatan tenaga kerja dari tahun 2017-2018. Sedangkan pemilihan UMKM segmen bisnis fashion, didasarkan pada fakta bahwa akibat tren Fast Fashion, sektor ini menjadi penyumbang emisi gas rumah kaca terbesar setelah semen serta logam-baja (www.cnnindonesia.com, 27/10/2015). Riset mengenai green intellectual capital sejauh ini masih sangat sedikit di Indonesia. Riset ini diharapkan dapat menjadi bukti empiris mengenai praktik green bisnis pada UMKM fashion khususnya yang ada di Jakarta.

\section{TELAAH LITERATUR}

Resource Based Theory menjelaskan bagaimana perusahaan memperoleh keunggulan kompetitif dan kinerja keuangan yang baik dengan cara memiliki, menguasai dan memanfaatkan aset-aset strategis yang penting bagi perusahaan (Hart, 1995). Resource Based Theory (RBT) dikembangkan untuk menganalisis keunggulan bersaing suatu perusahaan yang menonjolkan keunggulan pengetahuan (knowledge/learning economy) atau mengandalkan intangible assets (Firmansyah, 2017). Penelitian Delgado-verde et al., (2014) menyebutkan bahwa strategi dan keunggulan kompetitif masa depan bergantung pada kemampuan menjalankan kegiatan sustainable economic yang berdasarkan pelestarian lingkungan. Saat ini, karena meningkatnya kekhawatiran tentang masalah lingkungan, green intellectual capital dianggap mampu menciptakan motivasi keterlibatan karyawan pada aktivitas perlindungan lingkungan dan pemikiran keberlanjutan yang dapat mendorong keberlanjutan usaha (Mohd et al., 2019). Selain itu, sumberdaya tidak berwujud yang dimiliki perusahaan jika disinergikan dengan green bisnis akan mendukung pencapaian yang lebih ungul (Yi et al., 2019). Berdasarkan uraian di atas dapat disimpulkan bahwa jika perusahaan mampu mengelola green intellectual capital dengan efektif dan efisien maka akan dapat menciptakan sustainable performance bagi perusahaan. 
Studi intellectual capital telah menarik perhatian luas peneliti, dan pentingnya modal intellectual telah disorot dalam literatur manajemen. Namun, intellectual capital memasukkan konsep lingkungan dan green intellectual capital hanya diperkenalkan oleh penelitian Chen pada tahun 2008 (Yi et al., 2019). Green intellectual capital merupakan aset yang tidak berwujud atau sebagai pengetahuan yang terkait tentang manajemen lingkungan, gagasan organisasi dan sebagai perantara dalam sebuah inovasi produk yang ramah lingkungan (Delgado-verde et al., 2014). Green intellectual capital merupakan aktiva tidak berwujud yang dimiliki perusahaan termasuk pengetahuan, kebijaksanaan, pengalaman, dan inovasi dalam area perlindungan lingkungan (Mohd et al., 2019).

Penelitian ini, mengadopsi tiga elemen untuk menjelaskan green intellectual capital, yaitu green human capital, green structural capital, dan green relational capital (Mohd et al., 2019). Human Capital dianggap sebagai pengetahuan, keterampilan, kecerdasan, hubungan, sikap, bakat, dan perilaku karyawan (Maqableh et al., 2016). Pengetahuan lingkungan yang tertanam dalam karyawan adalah penting bagi perusahaan untuk mengembangkan green innovation dan green management untuk kepatuhan terhadap tekanan lingkungan (Mohd et al., 2019). Green human capital didefinisikan sebagai penjumlahan karyawan tentang pengetahuan, keterampilan, kemampuan, pengalaman, sikap, kebijaksanaan, kreativitas, dan komitmen, dll. Tentang perlindungan lingkungan atau inovasi hijau, dan tertanam di karyawan bukan di organisasi (Yusliza et al., 2019).

Green structural capital didefinisikan sebagai kemampuan organisasi, komitmen organisasi, manajemen pengetahuan sistem, sistem penghargaan, teknologi informasi sistem, database, mekanisme manajerial, proses operasi, filosofi manajerial, organisasi budaya, gambar perusahaan, paten, salinan hak, dan merek dagang, dll. Tentang perlindungan lingkungan atau inovasi hijau dalam suatu perusahaan (Yusliza et al., 2019). Green relational capital didefinisikan sebagai cadangan hubungan interaktif perusahan dengan pelanggan, pemasok, anggota jaringan, dan partner atas manajemen pengelolaan lingkungan dan green innovation (Firmansyah, 2017).

Sustainability adalah keseimbangan antara people-planet-profit, yang dikenal dengan konsep Tripple Bottom Line (TBL) dimana perusahaan harus bertanggung jawab terhadap dampak positif atau negatif yang ditimbulkan terhadap aspek ekonomi, sosial dan lingkungan (Tarigan, 2011). Laporan Brundtland tahun 1987 yang kemudian diterbitkan lebih lanjut oleh World Commission On Environment And Development tahun 1989 (Mohd et al., 2019) mengatakan bahwa:

"Development that meets the needs of the present generation without compromising the ability of future generations to meet their own needs, which commonly and widely used in literature and can be applied to these three composite outcomes namely economic, social and environmental."

Dari pernyataan di atas, sustainability dapat didefinisikan sebagai upaya pembangunan keberlanjutan pada saat ini tanpa mengabaikan kebutuhan generasi mendatang dengan melihat sisi ekonomi, sosial dan lingkungan. Sustainable memainkan peran penting dalam konteks manajemen, dan telah dikaitkan dengan tanggung jawab sosial perusahaan dengan menilai banyak dimensi seperti politik, sosial, budaya, ekonomi, dan lingkungan alam (Hussain, 2018). Yusliza et al., (2019) mendefinisikan sustainable performance dalam tiga kategori, yaitu economic performance, environmental performance, dan social performance. Economic performance adalah kemampuan organisasi untuk mengurangi biaya yang terkait dengan bahan yang dibeli, konsumsi energi, pengolahan limbah, pembuangan limbah, dan denda untuk kecelakaan lingkungan. Environmental performance didefinisikan sebagai kemampuan organisasi untuk mengurangi emisi udara, konsumsi energi, bahan berbahaya, penggunaan bahan, dan kepatuhan terhadap standar lingkungan. Social performance merupakan kemampuan organisasi untuk meningkatkan kesejahteraan dan perbaikan sosial, kesehatan dan keselamatan masyarakat, risiko bagi masyarakat umum, kesehatan kerja dan keselamatan karyawan (Yusliza et al., 2019).

Resource-based theory berasumsi bahwa suatu perusahaan akan memiliki kinerja yang baik dan daya saing yang tinggi apabila perusahan tersebut mampu mengelola sumber daya yang, salah satunya jika suatu perusahaan mampu menciptakan human capital yang unggul dan berkualitas. Hal tersebut diperkuat pada penelitian Mohd et al., (2019) mengatakan bahwa suatu perusahaan perlu meningkatkan kualitas sumber daya manusia secara efisien guna untuk menciptakan performance yang lebih baik. Hasil tersebut juga didukung oleh Yusliza et al., (2019) bahwa green human capital berpengaruh positif terhadap sustainable performance. Berdasarkan uraian diatas, maka hipotesis yang dapat dirumuskan:

H1: Green Human Capital berpengaruh positif terhadap Sustainable Performance

Resource Based Theory menyoroti mengenai kepemilikan sumber daya lingkungan dan bagaimana ke- 
mampuan perusahaan mengelola system lingkungan tersebut, pentingnya pengelolaan sistem sumber daya yang efektif dan efisien oleh perusahaan dapat menciptakan keunggulan kompetitif sehingga dapat menghasilkan nilai perusahaan (Firmansyah, 2017). Sebuah organisasi dengan structural capital yang kuat akan memiliki lingkungan pendukung yang kuat yang memotivasi karyawannya untuk belajar pengetahuan baru (Mohd et al., 2019). Penelitian Firmansyah, (2017) mengatakan bahwa investasi dalam green structural capital memungkinkan perusahaan untuk menghindari kerusakan lingkungan, meningkatkan produktivitas perusahaan, dan meningkatkan citra perusahaan yang memicu peningkatan economy performance maupun environmental performance. Seperti yang kita ketahui, dimana suatu perusahaan harus memiliki system sebagai dasar dari kegiatan operasional agar berjalan dengan efektif dan efisien sehingga mampu mencapai tujuan perusahaan tersebut. Hasil penelitian terdahulu seperti (Yusliza et al., 2019) membuktikan bahwa Green structural capital membantu organisasi dalam mengatur proses dan sistemnya, yang selanjutnya memungkinkan pengetahuan teknologi memainkan peran penting dalam mengembangkan green structural capital dalam mencapai sustainable performance yang lebih tinggi. Berdasarkan uraian diatas, maka hipotesis kedua adalah:

H2: Green Structural Capital berpengaruh positif terhadap Sustainable Performance

Hubungan yang baik terhadap pelanggan, karyawan dan pemasok mampu meningkatkan keunggulan bersaing, yang akan meningkatkan green intellectual capital perusahaan. Sebagaimana dinyatakan dalam Resource Based Theory dimana suatu perusahaan harus mengoptimalkan green intellecrual capital dengan menjalin hubungan yang baik antar karyawan, pemasok dan pelanggan (Yusliza et al., 2019). Penelitian Yi et al., (2019) memaparkan bahwa green relational capital sebagai hubungan interaktif perusahaan dengan pelanggan, pemasok, anggota jaringan, dan mitra tentang manajemen lingkungan perusahaan dan inovasi hijau, yang memungkinkannya untuk menciptakan kekayaan dan memperoleh keunggulan kompetitif. Penelitian Mohd et al., (2019) memberikan hasil bahwa green relational capital berpengaruh positif terhadap business sustainability, dimana mitra yang mampu berkolaborasi dan usaha yang memiliki banyak network connections sangat diperlukan untuk mempercepat dan meningkatkan sustainability. Sebagai tambahan, penelitian Delgado-verde et al., (2014) membuktikan bahwa manajemen perusahaan yang memiliki tanggung jawab sosial lingkungan dan memiliki kemampuan bersaing dapat mendorong pada kinerja yang sustainable. Berdasarkan uraian diatas, maka hipotesis yang dapat disimpulkan:

H3: Green Relational Capital berpengaruh positif terhadap Sustainable Performance

\section{METODE PENELITIAN}

Penelitian ini tergolong riset kausalitas yang bertujuan untuk menguji pengaruh green intellectual capital terhadap sustainable performance. Riset ini menggunakan pendekatan kuantitatif dengan populasi adalah UMKM bidang Fashion yang berada di Jabodetabek. Pengambilan sampel menggunakan teknik convenience sampling, teknik ini berupaya mendapat populasi target yang memenuhi kriteria praktis tertentu, seperti aksesibilitas mudah, kedekatan geografis, ketersediaan pada waktu tertentu, kemauan untuk berpartisipasi dimasukkan untuk tujuan penelitian serta sering kali responden terpilih karena mereka berada pada saat dan tempat yang tepat (Etikan et al., 2017). UMKM yang tergolong kedalam segmen fashion pada riset ini adalah usaha hijab, clothing brand, costume made clothing, fashion brand, fashion atelier, modest wear, clothing line, fashion muslim, distro, konveksi pakaian atau dengan kata lain, memiliki usaha yang membuat sendiri produk fashionnya. Daftar UMKM dijaring melalui browsing di Instagram dan Facebook. Selanjutnya, kuesioner dalam bentuk Google Form disebarkan kepada setiap UMKM yang di browsing melalui email, Direct Message Intagram dan Facebook, dimana satu responden akan mewakili satu UMKM. Responden target pada riset ini adalah pemilik atau karyawan, mengingat usaha UMKM biasanya tidak memiliki karyawan dalam jumlah banyak. Data primer yang diperoleh melalui survei kemudian dianalisis dengan menggunakan regresi linear berganda dengan bantuan software SPSS statistics 21, untuk kemudian dilanjutkan dengan pengujian hipotesis dan analisis statistik deskriptif.

Variabel terikat pada riset ini adalah sustainable performance diukur dengan mengggunakan tiga indikator antara lain economic sustainable, social sustainable dan environment sustainable yang merujuk pada Mohd et al., (2019). Sedangkan variabel independen dalam penelitian ini adalah green intellectual capital yang akan diukur melalui green human capital, green structural capital dan green relational capital. Skala pengukuran kuisioner adalah skala likert dari 1 sampai 7 dari sangat tidak setuju sampai dengan sangat setuju yang diadaptasi dari penelitian Mohd et al., (2019) dan Yusliza et al., (2019) . Berikut indikator atau meas- 
urement yang dideskripsikan dalam bentuk tabel operasionalisasi variabel:

Tabel 3.1 Operasionalisasi Variabel

\begin{tabular}{|c|c|c|c|}
\hline o. & Vari- & Alat Ukur & $\begin{array}{l}\text { Skala- } \\
\text { Pengukuran }\end{array}$ \\
\hline & $\begin{array}{l}\quad \text { Gree } \\
\text { n Human } \\
\text { Capital } \\
(\mathrm{GHC})\end{array}$ & $\begin{array}{l}\text { Variabel Green Intellectual Capital } \\
\text { (GHC 1): Kami berpartisipasi dalam kegiatan } \\
\text { produksi yang ramah lingkungan dan turut kontribusi } \\
\text { dalam kegiatan kepedulian lingkungan. } \\
\text { (GHC 2): Kami memiliki kemampuan yang } \\
\text { memadai dalam hal kepedulian lingkungan. } \\
\text { (GHC 3): Kami menghasilkan produk dan } \\
\text { layanan yang berkualitas tinggi dan ramah ling- } \\
\text { kungan. } \\
\text { (GHC 4): Kami memiliki tim yang bekerjasama } \\
\text { dengan baik dalam mencapai kepedulian lingkungan } \\
\text { (GHC 5): Manajer kami memberikan dukungan } \\
\text { penuh dalam kegiatan kepedulian lingkungan di ling- } \\
\text { kungan usaha kami. } \\
\text { (Mohd et al., 2019) }\end{array}$ & $\begin{array}{l}\text { Likert } \\
\text { Scale 1-7 }\end{array}$ \\
\hline & $\begin{array}{l}\quad \text { Gree } \\
\text { n Structural } \\
\text { Capital } \\
\text { (GSC) }\end{array}$ & $\begin{array}{l}\text { (GSC 1): Kami memiliki sistem manajemen } \\
\text { lingkungan yang baik. } \\
\text { (GSC 2): Usaha ini memiliki perbandingan staf } \\
\text { bidang manajemen lingkungan tehadap total karya- } \\
\text { wan yang tinggi. } \\
\text { (GSC 3): Kami memiliki investasi yang me- } \\
\text { madai dalam fasilitas perlindungan lingkungan. } \\
\text { (GSC 4): Operasional bisnis kami yang berori- } \\
\text { entasi lingkungan secara umum berjalan dengan } \\
\text { efisien. } \\
\text { (GSC 5): UMKM ini memiliki sistem mana- } \\
\text { jemen pengetahuan mengenai lingkungan yang } \\
\text { menguntungkan. } \\
\text { (GSC 6): Kami memiliki tim pemantau } \\
\text { operasional ramah lingkungan. } \\
\text { (GSC 7): Kami memiliki peraturan bisnis ramah } \\
\text { lingkungan yang rinci. } \\
\text { (GSC 8): Kami memiliki sistem penghargaan } \\
\text { bagi karyawan yang telah menjalankan upaya bisnis } \\
\text { yang ramah lingkungan. } \\
\text { (Mohd et al., 2019) }\end{array}$ & $\begin{array}{l}\text { Likert } \\
\text { Scale 1-7 }\end{array}$ \\
\hline & $\begin{array}{l}\quad \text { Gree } \\
\mathrm{n} \quad \text { Relational } \\
\text { Capital } \\
(\mathrm{GRC})\end{array}$ & $\begin{array}{l}\text { (GRC 1): Kami merancang produk atau jasa } \\
\text { yang ramah lingkungan yang sesuai dengan selera } \\
\text { pelanggan. } \\
\text { (GRC 2): Pelanggan puas dengan produk atau } \\
\text { jasa yang ramah lingkungan. } \\
\text { (GRC 3): Kami menjalin hubungan kerjasama } \\
\text { yang stabil dengan pemasok yang peduli dengan isu } \\
\text { lingkungan. } \\
\text { (GRC 4): Kami menjalin hubungan kerjasama } \\
\text { yang stabil dengan pelanggan yang peduli dengan isu }\end{array}$ & $\begin{array}{l}\text { Likert } \\
\text { Scale 1-7 }\end{array}$ \\
\hline
\end{tabular}


lingkungan.

(GRC 5): Kami menjalin hubungan kerjasama yang stabil dengan mitra strategis lainnya (pemerintah dil) yang peduli dengan isu lingkungan.

(Mohd et al., 2019)

\begin{tabular}{|c|c|c|}
\hline $\begin{array}{l}\text { Eco- } \\
\text { nomic Per- } \\
\text { formance } \\
(\mathrm{EP})\end{array}$ & $\begin{array}{l}\text { Variabel Sustainable Performance } \\
\text { (EP 1): Usaha kami memanfaatkan produk si- } \\
\text { sa/limbah untuk menghasilkan tambahan pendapa- } \\
\text { tan. } \\
\text { (EP 2): Usaha kami menghemat input/bahan } \\
\text { baku untuk mencapai tingkat output/pendapatan ter- } \\
\text { tentu tanpa mengabaikan aspek kualitas. } \\
\text { (EP 3): Untuk mencapai tingkat pendapatan } \\
\text { yang diinginkan, usaha kami berupaya melakukan } \\
\text { penghematan melalui manajemen limbah/produk si- } \\
\text { sa. (EP 4): Untuk melindungi kepentingan dan } \\
\text { keberadaan usaha, kami bekerja sama dengan staf dari } \\
\text { lembaga pemerintah. } \\
\text { (EP 5): Usaha kami menciptakan atau } \\
\text { menggunakan alat-alat produksi/teknologi yang } \\
\text { dapat digunakan secara fleksibel untuk memproduksi } \\
\text { beragam produk. } \\
\text { (EP 6): Usaha kami membedakan produk atau } \\
\text { proses produksi berdasarkan strategi pemasaran } \\
\text { produk/proses produksinya. } \\
\text { (Mohd et al., 2019) }\end{array}$ & $\begin{array}{l}\text { Likert } \\
\text { Scale 1-7 }\end{array}$ \\
\hline \begin{tabular}{l}
\multicolumn{1}{c}{ So- } \\
cial \\
Perfor- \\
mance (SP)
\end{tabular} & $\begin{array}{l}\text { (SP 1): Adanya peningkatan kesejahteraan } \\
\text { stakeholder/pemangku kepentingan secara kese- } \\
\text { luruhan. } \\
\text { (SP 2): Adanya peningkatan kesehatan sosial } \\
\text { masyarakat sekitar lingkungan usaha. } \\
\text { (SP 3): Adanya penurunan dampak negatif } \\
\text { maupun risiko usaha terhadap lingkungan dan } \\
\text { masyarakat. } \\
\text { (SP 4): Adanya peningkatan kesehatan dan } \\
\text { keamanan kerja karyawan. } \\
\text { (SP 5): Adanya peningkatan kesadaran dan } \\
\text { upaya perlidungan hak-hak pelanggan. } \\
\text { (Yusliza et al., 2019) }\end{array}$ & $\begin{array}{l}\text { Likert } \\
\text { Scale 1-7 }\end{array}$ \\
\hline $\begin{array}{l}\text { Envi- } \\
\text { ronment } \\
\text { Performance } \\
\text { (ENP) }\end{array}$ & $\begin{array}{l}\text { (ENP 1): Adanya peningkatan kepatuhan ter- } \\
\text { hadap standar peraturan lingkungan. } \\
\text { (ENP 2): Adanya penurunan emisi } \\
\text { udara/ tingkat pencemaran udara. } \\
\text { (ENP 3): Adanya penurunan konsumsi energi } \\
\text { (ENP 4): Adanya penurunan/penghematan } \\
\text { pada penggunaan bahan baku } \\
\text { (ENP 5): Adanya penurunan dalam } \\
\text { penggunaan zat-zat berbahaya. } \\
\text { (Yusliza et al., 2019) }\end{array}$ & $\begin{array}{l}\text { Likert } \\
\text { Scale 1-7 }\end{array}$ \\
\hline
\end{tabular}


Sumber: data diolah, 2020

\section{HASIL PENELITIAN DAN PEMBAHASAN}

Objek penelitian ini adalah UMKM yang bergerak di bidang Fashion. Fashion adalah ekspresi estetika pada gaya pakaian yang digunakan oleh seseorang dalam kesehariannya untuk menunjang penampilan. Industri fashion tidak hanya berkaitan dengan pakaian saja, namun terdapat aksesoris, kosmetik, dan gaya rambut yang popular pada waktu, masa dan tempat tertentu. UMKM Industri kreatif merupakan salah satu andalan yang diharapkan menjadi penopang roda perekonomian nasional. Hal tersebut di perkuat dalam data yang disajikan oleh (Investor.id, 2019) pada tahun 2019 industri kreatif memiliki kontribusi terhadap PDB Indonesia sebesar 7,55\% dengan estimasi angka mencapai Rp 1.100 triliun. Data dihimpun melalui kuesioner yang didistribusikan secara daring melalui google form. Kuesioner dikumpulkan selama 2 bulan dari tanggal 8 Mei 2020 hingga 1 Juli 2020 dengan total perolehan responden sebanyak 131 responden yang sekaligus mewakili UMKMnya. Terdapat 3 kuesioner yang tidak bisa digunakan karena tidak lengkap, sehingga total observasi adalah 128.

Hasil uji validitas menunjukan bahwa seluruh indikator yang terdapat di kuesioner dinyatakan valid karena telah memenuhi syarat uji validitas, dimana seluruh indikator memiliki nilai koefisien korelasi positif dan $r$ hitung lebih besar dari $r$ tabel. Uji reliabilitas dilakukan dengan melihat koefisien cronbach's $^{\prime}$ alpha. Hasil pengujian menunjukan bahwa seluruh indikator pengukuran dari variabel memiliki nilai Cronbach's Alpha lebih besar dari 0.6 yang berarti seluruh indikator variabel dalam penelitian ini dinyatakan reliabel.

Analisis deskriptif memaparkan karakteristik data dengan menggunakan kriteria nilai minimum, nilai maksimum, median, mean dan standard deviation. Berdasarkan data yang diperoleh, berikut hasil analisisnya:

Tabel 4.1 Analisis Statistik Deskriptif

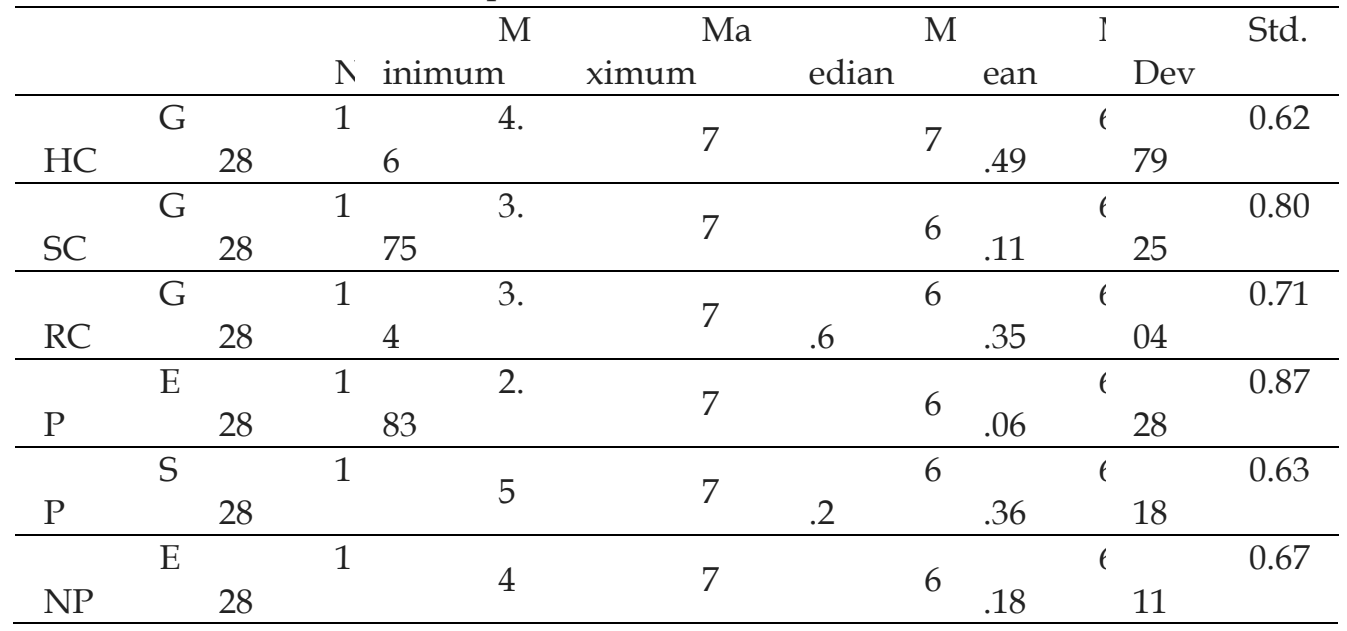

Sumber: data diolah, 2020

Table 4.1 di atas menunjukkan bahwa secara umum tingkat Green Human Capital (GHC) perusahaan sampel tergolong tinggi. Secara umum responden memahami urgensi praktik bisnis yang berkelanjutan dan setuju dengan pentingnya menjalankan bisnis dengan ramah lingkungan. Variasi jawaban responden terkait green human capital juga tergolong rendah. Data terkait Green Structural Capital (GSC) juga menunjukkan bahwa pelaku UMKM mendukung aspek green structural capital yang dalam penelitian ini ditunjukkan melalui rata-rata skor persepsi yang relatif tinggi. Variasi data green structural capital yang kecil menunjukkan bahwa tidak terdapat banyak perbedaan persepsi antara responden satu dengan yang lainnya. Data variabel independen Green Relational Capital (GRC) secara umum juga menunjukkan bahwa responden setuju dengan pernyataan mengenai GRC. Dengan kata lain pelaku UMKM fashion tersebut sepakat mengenai pentingnya menjalin Kerjasama dengan pemangku kepentingan untuk tercapainya kinerja bisnis yang berkelanjutan. Variasi jawaban responden terkait GRC juga kecil.

Economic Performance (EP) merupakan salah satu indikator dari variabel dependen Sustainable Per- 
formance, secara umum menunjukkan bahwa secara umum responden setuju bahwa komponen green intellectual capital dapat meningkatkan Economic Performance (EP). dalam menerapkan sustainability dalam bisnis mereka. Hasil yang sama juga terlihat pada variabel Social Performance (SP) dan Environment Performance (ENP).

Sebelum dilanjutkan dengan pengujian hipotesis, terlebih dahulu dilakukan pengujian normalitas dan uji asumsi klasik. Seluruh hasil pengujian menunjukkan bahwa data telah terdistribusi secara normal, tidak terdapat masalah heteroskedastisitas serta masalah multikolinearitas. Berikut adalah tabel hasil pengujian hipotesis.

Tabel 4.2 Hasil Uji Regresi

SustainablePerfromance $_{i}=5.321-0.293 \mathrm{GHC}_{\mathrm{i}}+0.089 \mathrm{GSC}_{\mathrm{i}}+0.349 \mathrm{GRC}_{\mathrm{i}}+\varepsilon$

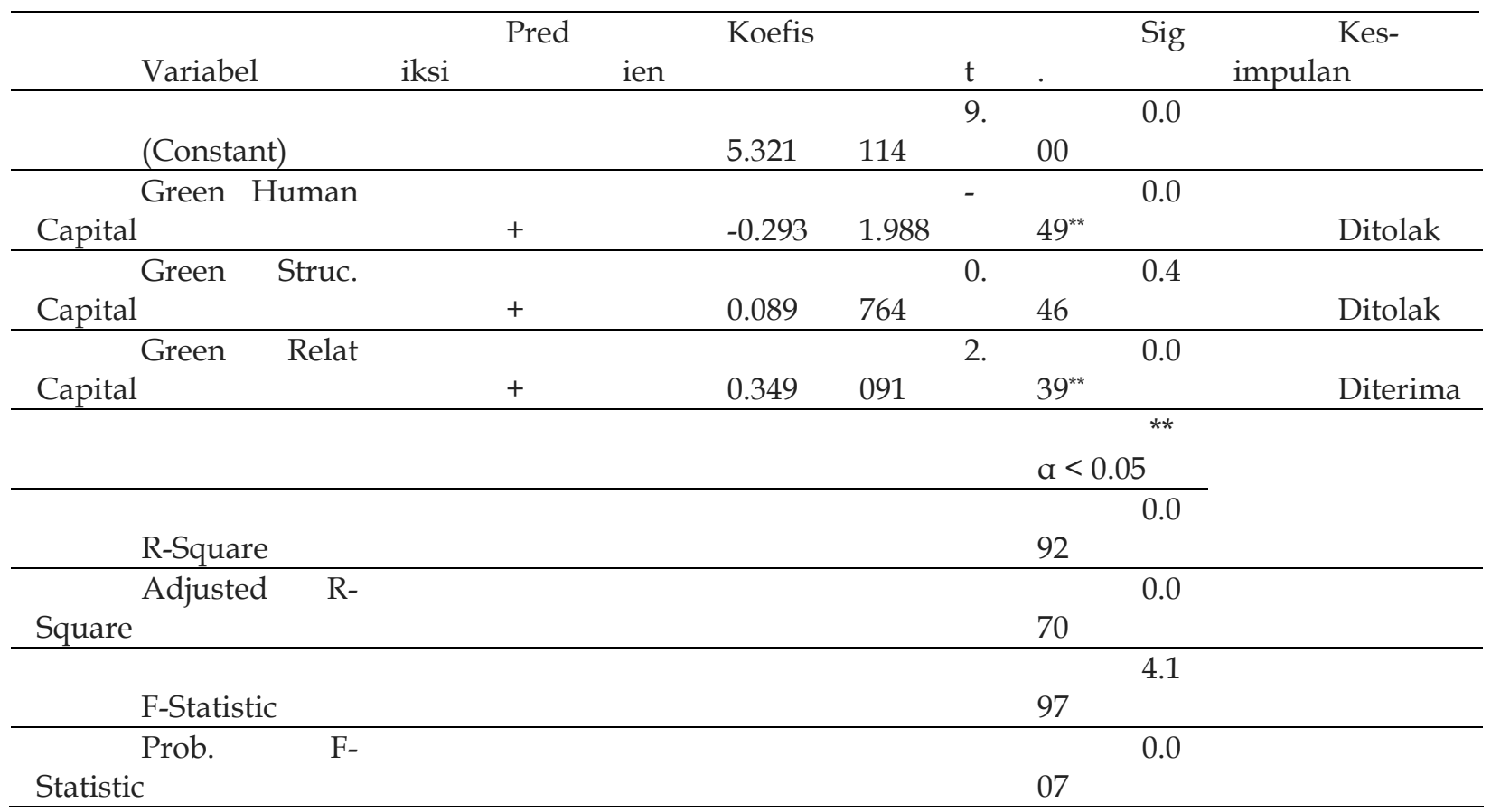

Sumber: data diolah, 2020

Pada tabel 4.2 di atas, dapat simpulkan bahwa variabel independen pada penelitian ini hanya mampu menjelaskan variabel dependen sebesar 7\%, dimana 93\% dijelaskan oleh faktor-faktor lain yang terdapat dari luar variabel yang diteliti. Hipotesis 1 menjelaskan mengenai pengaruh positif green human capital terhadap sustainable performance. Hasil pengujian menunjukkan bahwa green human capital berpengaruh negatif terhadap sustainable performance. Hal tersebut sejalan dengan hasil penelitian oleh Mohd et al.,(2019) dimana green human capital berpengaruh negatif terhadap sustainability. Temuan ini juga gagal mendukung prediksi dari The Resource Based Theory (RBT). Namun, hasil pada penelitian ini tidak sejalan dengan penelitian Yusliza et al.,(2019) yang menjelaskan bahwa green human capital berpengaruh positif terhadap sustainable performance. Kami menduga hasil yang berlawanan ini dipengaruhi oleh overconfidence responden dalam menjawab setiap pertanyaan, hal ini terlihat dari rata-rata jawaban responden untuk variable GHC tergolong tinggi mendekati 7. Sementara itu, masih tingginya kontribusi limbah fashion (85\% tidak di daur ulang; (pressrelease.kontan.co.id,) menunjukkan adanya kesenjangan antara jawaban dengan realita. Argumentasi lainnya adalah, untuk menciptakan sumber daya manusia yang memiliki pengetahuan mengenai sustainable bisnis, pelaku usaha setidaknya harus mengirim karyawannya atau mengikuti pelatihan mengenai sustainable fashion, yang tentunya tidak murah. Saat ini banyak sekolahsekolah mode yang sudah mulai menggunakan konsep sustainable fashion, misalnya sekolah mode milik asosiasi desainer Indonesia Fahion Chamber (IFC).

Hipotesis 2 menjelaskan mengenai pengaruh positif green structural capital terhadap sustainable performance pada UMKM fashion di Jakarta. Sebagaimana yang telah dijelaskan oleh Resource Based Theory, 
perusahaan yang memiliki dan mampu mengelola sistem lingkungan efektif dan efisien dapat menciptakan performance yang baik. Hasil pengujian menunjukkan bahwa green structural capital tidak berpengaruh terhadap sustainable performance. Hasil ini juga gagal mendukung prediksi dari The Resource Based Theory (RBT). Hal tersebut sejalan dengan hasil penelitian Yi et al., (2019) yang menjelaskan bahwa green structural capital tidak berpengaruh terhadap sustainable, namun penelitian ini tidak sejalan dengan dengan penelitian Yusliza et al., (2019) yang menjelaskan bahwa green structural capital memiliki pengaruh positif terhadap sustainable. Hasil penelitian ini didapatkan dari responden yang mayoritas merupakan pelaku bisnis UMKM fashion yang masih belum memiliki sistem managemen lingkungan dalam bisnis mereka, hal tersebut dikarenakan mayoritas responden dalam penelitian ini memiliki fashion bisnis yang masih dalam lingkup kecil, sehingga belum memiliki struktur organisasi dan system management yang mampu mendukung dalam menciptakan sustainable performance yang baik balam bisnis mereka.

Hipotesis 3 menjelaskan mengenai pengaruh positif green relational capital terhadap sustainable performance. Hasil pengujian hipotesis ketiga menunjukkan bahwa green relational capital berpengaruh positif terhadap sustainable performance. Hasil ini sejalan dengan prediksi The Resource Based Theory (RBT) yang juga didukung oleh penelitian (Yusliza et al., 2019). Hasil ini membuktikan bahwa kolaborasi atau kerjasama antara pelaku bisnis fashion dengan pelanggan terjalin dengan baik akan menciptakan sustainable performance dalam fashion bisnis mereka dengan baik. Hasil ini bermakna bahwa bukan hanya hubungan baik antara pelaku bisnis UMKM fashion dengan pelanggan saja, namun terjalinnya hubungan baik, kerjasama yang baik dan kolaborasi yang baik antara pemasok dengan fashion bisnis tersebut. Pemasok yang dimaksud adalah mereka yang menyediakan produk kain yang sustain, dimana kain tersebut terbuat dari serat alam. Dengan demikian, apabila kolaborasi antara pemasok, pelaku bisnis dan pelanggan terjalin baik, hal tersebut dapat meningkatkan sustainable performance di dalam fashion bisnis tersebut.

Riset ini menemukan bahwa green human capital berpengaruh negatif terhadap sustainable performance. Hasil ini sebenarnya selaras dengan fakta dilapangan, bahwa dalam menciptakan produk/jasa yang ramah lingkungan di Indonesia membutuhkan biaya yang cenderung lebih mahal dibandingkan produk konvensional. Ada faktor economics of scale yang bermain, sehingga tidak jarang membuat biaya produksi menjadi lebih tinggi. Produsen juga akan lebih dibebani dengan biaya pelatihan green bisnis yang kadang tidak murah serta menyita waktu produktif karyawan. Setelah produk jadi, produsen juga dihadapkan pada masalah penentuan harga jual. Harga yang relatif lebih tinggi, tentunya akan menurunkan profit yang diperoleh. Untuk itu, diperlukan ekosistem bisnis ramah lingkungan yang lebih besar, yang membutuhkan dukungan dari regulator, kelompok usaha, pembiayaan yang rendah bunga dari berbagai pihak terkait. Sinergi para pelaku UMKM fashion dengan konsep produksi ramah lingkungan dapat meningkatkan keuntungan mereka.

Tidak adanya pengaruh antara green structural capital terhadap sustainable performance dalam riset ini bukan berarti aspek ini dapat diabaikan. Justru bisa bermakna sebaliknya, ketiadaan sistem dan struktur management lingkungan pada bisnis fahion akan membuat sulitnya memperoleh manfaat dari penerapan praktik bisnis yang ramah lingkungan. Pelatihan dan motivasi sertifikasi seperti ISO 14001 dapat membantu UMKM dalam melindungi lingkungan dan sekaligus memenuhi kebutuhan sosial dan ekonomi (ISO, 2015). Secara bertahap kementerian terkait dapat mendorong UMKM untuk menghasilkan produk ataupun proses bisnis yang tersertifikasi.

Riset ini membuktikan pengaruh positif antara green relational capital dengan sustainable performance, yang berarti kerjasama yang baik antara pemasok, pelaku bisnis dan pelanggan yang berkaitan dengan sustainable adalah salah satu indikator yang harus terus diperhatikan dan ditingkatkan suatu UMKM fashion bisnis demi tercapainya sustainable performance yang baik. Rancangan desain supply chain bagi bisnis fashion, kerjasama dengan asosiasi perancang busana, dengan supplier bahan baku serta regulator akan memperkuat aspek green relational capital.

\section{SIMPULAN, KETERBATASAN, DAN SARAN}

Penelitian ini bertujuan untuk melihat pengaruh komponen green intellectual capital terhadap sustainable performance pada UMKM fashion di Jakarta. Hasil pada penelitian ini menunjukkan bahwa variabel green intellectual capital yang diukur dengan proksi green human capital berpengaruh negatif terhadap sustainable performance, green structural capital tidak berpengaruh terhadap sustainable performance dan green relational capital ditemukan memiliki pengaruh positif terhadap sustainable performance.

Riset ini memiliki sejumlah keterbatasan, dengan mengandalkan market place dan media sosial da- 
lam memperoleh responden dan menyebarkan kuesioner menyebabkan responden dengan berbagai tingkat skala usaha dapat menjadi responden. Sehingga terdapat perbedaan ukuran usaha akan mempengaruhi jumlah serta demografi karyawan yang mungkin dapat mempengaruhi persepsi mereka mengenai green business. Riset berikutnya dapat memilih responden dengan kriteria skala usaha, kriteria demografi dan segmen usaha yang homogen, sehingga akurasi persepsi dapat lebih ditingkatkan.

\section{DAFTAR PUSTAKA}

Bank Indonesia, L. (2015). Profil bisnis usaha mikro, kecil dan menengah (umkm).

Chen, Y., \& Chen, Y. (2008). The Positive Effect of Green Intellectual Capital on Competitive Advantages of Firms. J Bus Ethics 77, 271-286. https:// doi.org/10.1007/s10551-006-9349-1

Delgado-verde, M., Amores-salvadó, J., Martín-de, G., \& Navas-lópez, J. E. (2014). Green intellectual capital and environmental product innovation: the mediating role of green social capital. Knowl Manage Res Pract 12, 261-275. https:/ / doi.org/10.1057/ kmrp.2014.1

Depkop.go.id. (2018). Perkembangan Data UMKM dan UB Tahun 2017-2018. Retrieved from http://www.depkop.go.id/data-umkm

Firmansyah, A. (2017). Pengaruh Green Intellectual Capital dan Organizational Identity Dan Dampaknya Terhadap Green Competitive Advantage. Jurnal Substansi, Vol. 1 (1), 183-219. DOI: $10.35837 /$ subs.v1i1.215

Hart, S. L. (1995). A Natural-Resource-Based View Of The Firm. 20.

Hussain, F. A. H. and M. (2018). Sustainable organizational performance A study of health-care organizations in the United Arab Emirates. https:/ / doi.org/10.1108/IJOA-10-2017-1263

Ilker Etikan, Sulaiman Abubakar Musa, R. S. A. (2017). Comparison of Convenience Sampling and Purposive Sampling Comparison of Convenience Sampling and Purposive Sampling. (February). https://doi.org/10.11648/j.ajtas.20160501.11

Investor.id. (2019). Kontribusi Industri Kreatif terhadap PDB 2019 Diproyeksikan 7,55\%. Retrieved from https:/ /investor.id/ business/ kontribusi-industri-kreatif-terhadap-pdb-2019-diproyeksikan-755

ISO, O. B. P. (2015). ISO 14001:2015(en) Environmental management systems. Retrieved from https://www.iso.org/obp/ui/\#iso:std:iso:14001:ed-3:v1:en

ISO, O. B. P. (2019). ISO 14005:2019(en) Environmental management systems. Retrieved from https://www.iso.org/obp/ui/\#iso:std:iso:14005:ed-2:v1:en

Jameelah, M., Osman, I., \& Musa, S. (2015). Effect of Intellectual Capital on Organizational Performance. Procedia- Social and Behavioral Sciences. Vol. 211 (September), pages 207-214. https://doi.org/10.1016/j.sbspro.2015.11.085 Lembaga.

Koperasi\&UMKM, K. (2019). Sinergitas Pengembangan KUMKM melalui Penguatan Peran Antar

Maqableh, M., Yousef Obeidat, B., Bahjat Abdallah, A., Akhoershiedah, A. H. O. M., \& Osama Aqqad, N. (2016). The Effect of Intellectual Capital on Organizational Performance: The Mediating Role of Knowledge Sharing. Communications and Network, 09(01), 1-27. https://doi.org/10.4236/cn.2017.91001

Masnidar, L. (2017). Statistik Deskriptif. Hikmah 14(1), 49-55.

Mohd, Y., Khalil, M., Delima, M., \& Zaman, K. (2019). Do all elements of green intellectual capital contribute toward business sustainability? Evidence from the Malaysian context using the Partial Least Squares method. Journal of Cleaner Production, 234, 626-637. https://doi.org/10.1016/j.jclepro.2019.06.153

Panuluh, S., \& Fitri, M. R. (2016). Pelaksanaan Sustainable Development Goals ( SDGs ) di Indonesia. (September). www.sdg2030indonesia.org

Sayyidah, U., \& Saifi, M. (2015). Pengaruh Intellectual Capital Terhadap Nilai Perusahaan Variabel Moderasi ( Studi Pada Perusahaan Sub Sektor Property Dan Real Estate Di Bursa Efek Indonesia Periode 2013-2015 ). 46(1), 163-171.

SDG2030indonesia.org. (2017). Sustainable Development Goals. Retrieved from https://www.sdg2030indonesia.org/page/1-tujuan-sdg

Secundo, G., Ndou, V., Del, P., \& Pascale, G. De. (2020). Technological Forecasting \& Social Change Sustainable development, intellectual capital and technology policies : A structured literature review and future research agenda. Technological Forecasting \& Social Change, 153(July 2019), 119917. https:// doi.org/10.1016/j.techfore.2020.119917 
Sindonews.com. (2019). Penerapan SDGs Bantu Perusahaan di Indonesia untuk Bertumbuh. Retrieved from https://ekbis.sindonews.com/read/1468846/33/penerapan-sdgs-bantu-perusahaan-diindonesia-untuk-bertumbuh-1576208626

Tarigan, R. N. dan J. (2014). Pengaruh Sustainability Reporting Terhadap Kinerja Keuangan Perusahaan Publik Dari Sisi Profitability Ratio. Business Accounting Review, Vol 2, No. 1, 111-120.

Ullah, H., Wang, Z., Bashir, S. et al. (2021). Nexus between IT capability and green intellectual capital on sustainable businesses: evidence from emerging economies. Environ Sci Pollut Res. https://doi.org/10.1007/s11356-020-12245-2

Wang, C. H., \& Juo, W. J. (2021). An environmental policy of green intellectual capital: Green innovation strategy for performance sustainability. Business Strategy and the Environment. https:// doi.org/10.1002/bse.2800

Yanti, V. A., Amanah, S., \& Muldjono, P. (2018). Faktor yang mempengaruhi keberlanjutan usaha mikro kecil menengah di Bandung dan Bogor. Jurnal Pengkajian dan Pengembangan Teknologi Pertanian, Vol. 20, No.2, 137-148.

Yi, J., Yusliza, M., Ramayah, T., \& Fawehinmi, O. (2019). Nexus between green intellectual capital and green human resource management. Journal of Cleaner Production, 215, 364-374. https://doi.org/10.1016/j.jclepro.2018.12.306

Yusliza, M., Yong, J. Y., Tanveer, M. I., Ramayah, T., Juhari, N. F., \& Muhammad, Z. (2019). A structural model of the impact of green intellectual capital on sustainable performance. Journal of Cleaner Production, 119334. https:/ / doi.org/10.1016/j.jclepro.2019.119334

Yusoff, Y.M.; Omar, M.K.; Zaman, M.D.K.; Samad, S. 2019. Do all elements of green intellectual capital contribute toward business sustainability? Evidence from the malaysian context using the partial least squares method. J. Clean. Prod. 234, 626-637

Zuliyati, N. A. B., \& Delima, Z. M. (2017). Pengaruh Intellectual Capital Terhadap Kinerja UMKM. Jurnal Akuntansi dan Keuangan 6(2), 181-200. 